\title{
PLATÃO ALÉM DO DOGMATISMO
}

Alcides Hector Rodriguez BENOIT ${ }^{1}$

- RESUMO: Este artigo procura mostrar as dificuldades existentes para sustentar a interpretação dogmática de Platão e, a partir daí, indicar algumas reflexões sobre as relações entre dogmatismo, ceticismo e dialética.

- PALAVRAS-CHAVE: Platonismo; dogmatismo; ceticismo; dialética.

\section{Existem os dogmas de Platão?}

"Sextus distingue três filosofias. De Platão ele não sabe o que fazer."

Hegel $^{2}$

A palavra grega dogma era já utilizada por Platão. Lê-se, por exemplo, na República (538c): "Temos desde a infância dogmas (dógmata) sobre as coisas justas e belas que ... temos o hábito de seguir e de respeitar." Neste caso, "dógmata" significa apenas "opiniões" ou "máximas", não possuindo ainda um sentido mais rigoroso. No entanto, já ao final do século IV e começo do III a.C., esta palavra evoluirá semanticamente e significará "os elementos de uma doutrina filosófica". Sobretudo a partir do ceticismo de Pirron, passou-se a opor "os dogmáticos" (oi dogmatikoi) - aristotélicos, epicuristas e estóicos - aos "céticos" (skeptikoi) - aqueles que não sustentam nenhuma doutrina positiva.

Tomando a palavra dóg mata neste último sentido - elementos de uma doutrina positiva -, sentido já consagrado na história da Filosofia Antiga, parece hoje estranho perguntar: existiriam os dogmas de Platão? Existiriam nos Diálogos de Platão dogmas

1 Professor do Departamento de Filosofia da Unicamp - 13081-970 - Campinas - SP - Brasil.

2 "Sextus unterscheidet drei Philosophien. Mit Plato weiss er nicht, was anzufangen...". (Hegel, 1965, p.253) 
ou elementos afirmativos que constituem uma doutrina filosófica positiva? Existiria uma doutrina "dogmática" em Platão? Parecem hoje um pouco estranhas tais perguntas já que, desde a infância, o senso comum e a própria Filosofia ocidental nos acostumaram a aprender e descrever dogmaticamente uma multiplicidade de dógmata platônicos que constituiria senão um sistema, ao menos, certamente, uma doutrina filosófica razoavelmente construída e delimitada em suas fronteiras. Questionar a existência desta doutrina "dogmática" é hoje tarefa pouco praticada pelos comentadores filosóficos de Platão. Parece hoje quase impossível questionar, até mesmo, apesar das múltiplas interpretações divergentes e até em certos pontos conflitantes que tal suposta doutrina de Platão possua como núcleo dos seus dógmata a célebre "Teoria das Idéias". Realmente, parece bastante estabelecido por centenas de exegetas e historiadores da Filosofia que seria em torno da "teoria das idéias" que se desenvolvem e se estruturam os outros múltiplos dógmata que foram encontrados no interior dos Diálogos: a teoria da reminiscência, aquela da imortalidade da alma, aquela da mímesis, a teoria do conhecimento, a paidéia platônica, o eros platônico, o projeto de cidade e a própria dialética. ${ }^{3}$

\section{O dogma das Idéias}

“ ...mála geloiôs ... " (República, 509c)

Quase todos os comentadores são também unânimes em apontar quais são as páginas privilegiadas para a descrição de tal teoria nuclear estruturadora de toda a dogmática platônica: sem dúvida, aquelas do livro VI da República. Recordemos brevemente. Nesse livro, Sócrates sustenta a existência de uma região das coisas visíveis e de outra das coisas inteligíveis, a região das Idéias (Rep.VI, 509d-510a). Como se sabe, a primeira região é subdividida em duas partes, aquela das meras imagens - sombras, reflexos, espelhamentos - e em seguida, aquela dos corpos sensiveis em geral - animais, plantas, objetos naturais e produzidos pela arte dos homens (510a). A segunda região geral, a dos seres inteligíveis, por sua vez, é também subdividida: em sua primeira parte existiriam idéias ainda apoiadas em elementos do sensivel, estes últimos seriam a matéria para a construção de raciocínios hipotéticos e deduções inteligíveis, este é o domínio intermediário, região por excelência das matemáticas; finalmente, na outra e derradeira parte se atingiriam as idéias puras que

3 São exceções aqueles que observam como Woodruff (1986, p.22): “we have rarely taken the trouble to ask whether Plato promulgated doctrines at all. Much is written nowadays about a Theory of Forms. When did Plato develop it? Did he derive it from Socrates? Did hie modify it in later years? But we should ask first whether Plato's dialogues taught a theory of Forms at all". 
dariam acesso ao princípio absoluto, princípio não-hipotético (anypóthetos), que sena o Bem (510b). Este, como princípio absoluto, como Idéia das Idéias, possuiria uma "divina transcendência" (daimonías hyperbolês - 509c), seria dele que emanaria todo o processo do conhecimento, dele os objetos do conhecimento humano receberiam a sua cognoscibilidade, o seu ser (tó einai) e a sua essência (ousia), ainda que ele próprio, o Bem, não seja ousia - como afirma-se em 509b - "mas sim, algo que ultrapassa de longe a ousia em majestade e potência".

Sem dúvida, aqui, nestas breves páginas da República, já estão contidos os dogmas principais da chamada "Teoria das Idéias": as duas regiões gerais - a do sensível e a do inteligível - as suas subdivisões e finalmente a Idéia epékeina tês ousias, a idéia "além da ousia", a idéia de Bem como idéia das idéias que, da sua fixidez transcendente, emana a fundamentação ontológica de todos os seres inferiores.

Estas páginas foram sempre privilegiadas na descrição da doutrina platônica das idéias, desde Aristóteles e o Neoplatonismo até os recentes comentadores contemporâneos. Por exemplo, ainda Goldschmidt escrevia: "As Formas constituem um conjunto organizado. Quanto à Forma do Bem, coloca-se no topo do sistema. Ela comunica a todas as Formas existência e essência, mas ela própria está ainda além da essência". ${ }^{4}$ Da mesma forma, já na Antigüidade escrevia Proclus (1970, tomo II, p.72) a partir daquelas passagens da República: "há uma espécie de Um que não é o Ser e que no entanto é o mais alto objeto das ciências para aqueles que conhecem os Seres, um Um tal como Sócrates diz que é o Bem". E explicando-nos o Bem, em outra passagem, escreveu Proclus (idem, p.88): "segundo Platão, o Bem é acima da essência dos Inteligíveis e verdadeiramente hiperessencial (hyperousion)." Da mesma forma, embasada principalmente no livro VI, parece ser a descrição da teoria das idéias feita por Aristóteles sobretudo no livro "A" da Metafísica. Após apontar a separação existente entre os seres sensíveis e as idéias, ${ }^{5}$ ressalta ainda Aristóteles, conforme a doutrina "dogmática" da República, a particularidade dos seres matemáticos enquanto entes intermediários que, em certo sentido, participariam de ambos os domínios. ${ }^{6}$ Como se sabe, muitas e muitas páginas similares poderíamos ainda citar, tanto de comentadores antigos como modernos, que estruturam a "doutrina" platônica em torno das proposições do livro VI.

Possuem, no entanto, estes dogmas, através dos diversos outros Diálogos, realmente uma coerência doutrinária? Ao examinarmos outros Diálogos de Platão e

\footnotetext{
4 Goldschmidt, 1962, p.43-44; para apoiar as suas afirmações, Goldschmidt citava aqui E. Bréhier que similarmente escrevia: "Em Platão ele (o Bem) não adquire sentido senão neste sistema; ele é a idéia suprema; mas é ainda uma idéia." (In: La Philosophie de Plotin, p. 147).

5 Em Aristóteles, 1958, p.987b-7, escreve Aristóteles: (Platão) "denominou tais entes idéias, acrescentando que as coisas sensiveis estão fora destas, mas segundo as idéias são ditas todas as coisas; pois por participação as coisas múltiplas ṡão homônimas às idéias."

6 Em Aristóteles, 1958, p.987b, l. 14-16, se lê: "Além disso, a o lado das coisas sensiveis e das idéias, admite (Platão) as coisas matemáticas como sendo entre (metaxu)."
} 
contemplarmos o reaparecimento da mesma problemática, estes dogmas se preservam com a positividade que, ao menos supostamente, recebem na República? A positividade dogmática da "teoria das idéias" que por tantos séculos foi atribuída ao pensamento de Platão e que serviu como teoria nuclear para a exposição, ensinamento e estruturação do "sistema" de Platão subsiste sem contradições através da dialética geral dos Diálogos? Reexaminemos algumas passagens dos Diálogos na sua literalidade dialógico-dramática.

Tomando o diálogo Parmênides, lá encontramos, mais uma vez (ou talvez antes, já que lá Sócrates é descrito como ainda muito jovem), a discussão da Teoria das Idéias. Sustenta Sócrates logo ao início do diálogo que existe uma idéia em si e por si (autó kath' autó) da semelhança e da dissemelhança. Aquilo que participa da semelhança torna-se semelhante, e o que participa da dissemelhança, diz ele, torna-se dissemelhante, (Platão, p.128e-129a). Mais adiante, dialogando com Parmênides, concorda o jovem Sócrates que, segundo a sua teoria, existe uma idéia em si e por si (ti eidos autó kath' autó) do justo, do belo, do bem e de todas essas noções similares (Idem, p.130b). O mesmo ocorreria em relação a seres sensíveis. Existiria uma idéia separada (cônis) do homem, do fogo e da água (Idem, p.130c). Portanto, sustenta-se aqui aproximadamente a mesma doutrina desenvolvida na República, os mesmos dogmas da teoria das idéias, tal como foram celebrados pela longa tradição interpretativa. No entanto, paradoxalmente, se a teoria das idéias é de fato aqui mais uma vez apresentada, 0 desenvolvimento dramático do diálogo não a confirmará. Ao contrário, as páginas seguintes (Idem, p.130c-134e) apresentarão justamente uma série de aporias na qual se envolve o jovem Sócrates e todo aquele que hipoteticamente sustentasse tal doutrina. 0 próprio Platão estaria assim, em seus próprios Diálogos, colocando dificuldades para a sua própria doutrina? Ou seriam estas apenas páginas isoladas e, como afirmaram diversos comentadores, apenas meros exercícios acadêmicos de dialética?

A verdade é que, apesar de contraditórias e profundamente negativas em relação à dogmática das idéias, estas páginas do Parmênides não podem ser minimizadas. Afinal, ali estão contidos todos os argumentos das principais críticas que posteriormente foram formuladas contra a Teoria das Idéias e, sobretudo, mesmo aqueles argumentos que iniciaram a longa série de polêmicas contra tal suposta dogmática de Platão: os célebres argumentos de Aristóteles.

Os problemas começam para Sócrates quando não sabe responder se existiriam idéias mesmo de coisas ínfimas como um fio de cabelo ou coisas não nobres como a sujeira (Idem, p.130c-e). Em seguida, as dificuldades tornam-se maiores quando começa-se a investigar de que maneira ocorre o processo de participação entre as idéias e as coisas sensíveis. Sócrates inicialmente sugere que as idéias encobririam ou envolveriam as coisas sensiveis, como um véu encobre o que está sob ele ou como a luz do dia envolve as coisas que ilumina. Parmênides lhe mostra que através dessas formas a própria idéia se dividiria e não seria mais um Um sobre o Múltiplo (Idem, p.130e-131e). A seguir, Sócrates levanta a hipótese da idéia como uma unidade 
sintética e Parmênides lhe mostra que desta maneira se cairia no paradoxo da infinitude das idéias, sempre seriam necessárias novas idéias para unificar as anteriores. ${ }^{7}$ Surge então a hipótese da idéia como conceito, existiria a identidade entre o pensamento e o objeto pensado e assim se explicaria o processo de participação entre o sensível e o inteligível. Parmênides, no entanto, mais uma vez, mostra as novas dificuldades: tudo se transformaria em idéia e desapareceria o próprio sensível (Idem, p.132b-c). Sócrates sugere então que a idéia poderia ser concebida como um paradigma que modelaria o sensível, este seria assim uma cópia do inteligível. Parmênides novamente demonstra a impossibilidade de tal solução recorrendo ao paradoxo do $3^{\circ}$ Homem (Idem, p.132c-133a). Diante de tantas dificuldades, Parmênides sugere que as idéias, mesmo existindo, seriam incognoscíveis para o homem (Idem, p.133a-134c), ou então, que o mundo divino das idéias não se comunicaria e não conheceria o mundo humano (Idem, p.134c-134e); ambas as hipóteses parecem inaceitáveis para o jovem Sócrates, mas não encontrará saída, ao menos neste diálogo, para a situação aporética que se instaurou sobre a teoria das idéias. Assim é que Parmênides, impiedoso, lhe perguntará: "Que farás da filosofia? Para onde te voltarás se não tens resposta para estas questões?" E quase balbuciante, reconhecerá o jovem que, ao menos no presente, não vislumbra nenhum caminho (Idem, p.135c).

Como observa corretamente Diès (1965, p.25-6), estão aqui nesta passagem do Parmênides praticamente todos os argumentos que depois serão de maneira insistente levantados por Aristóteles: "Dificuldades da participação, impossibilidade de justificar a unidade da forma, inutilidade científica da duplificação que tal teoria sobrepõe ao real, estão aí as objeções sobre as quais Aristóteles s'étendra à plaisir". Diès, no entanto, apesar de reconhecer a gravidade do problema, se abstém, como a maioria dos comentadores contemporâneos, de pensar mais seriamente as conseqüências desse texto para os dógmata das idéias. ${ }^{8}$ Ora, Platão - com "clareza impiedosa", antes de Aristóteles - teria realizado uma crítica devastadora contra a sua própria teoria central? Platão, antes de Aristóteles, teria destruído os dógmata nucleares de sua doutrina, aqueles que estruturam os seus outros dógmata? No século XIX, os comentadores perceberam a existência do problema e, sobretudo, preocuparam-se com as conseqüências teóricas que esta crítica possuiria para a interpretação da posterior crítica (praticamente a mesma) realizada por Aristóteles. A solução primeira encontrada foi considerar apócrifo o diálogo Parmênides. ${ }^{9}$ Com os estudos estilísticos quantitativos (Campbell, Ritter, Lutoslawski) desenvolvidos na segunda metade do século XIX, no entanto, esta "solução" mostrou-se inviável, já que foi confirmada a

7 Platão, 1956 p.132a-b.; trata-se, evidentemente, do paradoxo conhecido, a partir de Aristóteles, como "paradoxo do $3^{\circ}$ Homem".

8 Assim, escreve Diès (1965, p.26): "Quelque jugement que l'on doive porter sur leur valeur, il faut reconnaitre que le Parménide de Platon les expose avec une logique dont la clarté impitoyable ne sera pas dépassée".

9 Nesse sentido, ver, por exemplo, Ueberweg (1861), capitulo intitulado "Für die Unechtheit der Dialoge", e particularmente, em relação ao Parmênides, p.176-84, em que Ueberweg sustenta a inautenticidade deste diálogo. 
autenticidade estilística deste diálogo. Em seguida, a "solução" predominante, embasada justamente na cronologia advinda dos estudos estilísticos, foi descrever uma suposta "evolução" no pensamento platônico. O Parmênides seria um diálogo escrito no fim da vida de Platão, e portanto expressaria uma "crise" do "sistema" platônico. Mas também esta "solução" foi abandonada, sobretudo a partir da segunda metade do século XX, quando, com o desenvolvimento da análise estrutural na história da Filosofia (Goldschmidt), caiu em descrédito toda tentativa de explicação dita "evolucionista". Então, em relação às contradições existentes entre a "Teoria das Idéias" da República e o diálogo Parmênides, restou como "solução", até hoje predominante, apenas o infeliz contentar-se, mais e mais, com o estudo separado de cada um desses diálogos. Colaborou nesse sentido o descrédito sempre crescente das chamadas "macroanálises do século XIX". No entanto, no nível dos manuais de história da Filosofia se preserva a "macrodogmática" ancorada na República e, em geral, ela reaparece, ao menos parcialmente, em quase todos os estudos monográficos a respeito de conceitos ou diálogos específicos de Platão.

Mas, contra esse infeliz contentar-se das "rigorosas" microanálises contemporâneas (ancoradas naquela antiga "macrodogmática"), é necessário sempre recordar os problemas que o "velho" século XIX tentou sem sucesso resolver: as célebres páginas do livro VI da República, apesar de ainda hoje serem apresentadas nos manuais de história da Filosofia como contendo os definitivos dógmata de Platão, não podem ter uma validade absoluta no interior da obra platônica. É o que parecem apontar, além do Parmênides, também outros diálogos, como o Filebo e o Sofista.

Recordemos, primeiramente, algumas páginas do Sofista. Os interlocutores, após discutirem a posição dos materialistas - "os filhos da terra" -, passam a estudar a doutrina dos "amigos das idéias" ${ }^{10}$ Esta parece ser, realmente, a doutrina sustentada por Sócrates na República, no Parmênides (ainda que de maneira malsucedida) e também em alguns outros diálogos, como o Fédon. Para "os amigos das idéias" explica o Estrangeiro - a ousia ou essência é pensada como separada (cônis) do devir. ${ }^{11}$ Segundo "os amigos das idéias", por um lado, pelo corpo, através da sensação, possuímos participação com o devir; por outro lado, pela alma, através do raciocínio, participamos da "essência que é plenamente". ${ }^{12}$ Esta última - esclarece ainda o Estrangeiro - seria segundo "os amigos das idéias" sempre identicamente imutável, enquanto aquilo que está mergulhado no devir varia a cada instante..$^{13}$ Assim, descrevem-se aqui, como no livro VI da República, os domínios do sensível e do inteligível, no entanto, paradoxalmente - ao menos para Sócrates e o dogma das idéias --, como já ocorrera no Parmênides, mais uma vez, esta doutrina será contestada. Sem que

10 Sofista, (Platão, 1956, p.248a): "Passemos portanto aos outros, aos Amigos das Idéias (tous toon eidoon phílous)". 11 Idem, ibidem.

12 Idem, ibidem: "prós tén ontoos ousían".

13 Idem, ibidem. 
agora acompanhemos os detalhes da refutação, é particularmente importante a crítica que se desenvolverá contra a idéia suprema, que na República seria a idéia das idéias, o Bem, algo epekeina tês ousias, "algo além da ousia" (Platão, República, p.509b). Aqui o Estrangeiro de Eléia se refere "ao Ser absoluto" (panteloos onti (Platão, Sofista, p.248e)) justamente para, contra a célebre teoria da República, negar-lhe a sua imóvel e indescritível transcendência. Nessa direção, em passagem decisiva, como se estivesse polemizando diretamente com o Sócrates da República, ${ }_{1}^{14}$ pergunta 0 Estrangeiro: "Nós nos deixaremos tão facilmente convencer de que o movimento, a vida, a alma, o pensamento realmente não estão presentes no ser absoluto, que ele não vive nem pensa, e que, solene e sagrado, não tendo intelecto, imóvel (akinêton) é algo que permanece fixo?" (Platão, p.248e-249a). Na seqüência do texto, Teeteto e o Estrangeiro concordam que é necessário atribuir ao Ser : intelecto, vida, psique e finalmente o próprio movimento (kínesis) (Idem, p.249a-b). Ora, com essa multiplicidade de predicações que recebe o Ser absoluto e, principalmente, com esta última, a predicação do movimento, nada mais resta da "divina transcendência" que possuía o Bem socrático, absoluto impredicável, lançado acima e além da própria noção de ousia. Agora, o Ser no seu sentido mais absoluto recebe uma multiplicidade de predicações e mesmo predicações contraditórias, tais como o movimento e o repouso. Assim diz o Estrangeiro que não devemos ouvir nem os que defendem a imobilidade do Ser (Parmênides e os "amigos das idéias"), nem os que sustentam o devir absoluto (os heraclitianos e os "filhos da terra"), mas é preciso "fazer seu, como as crianças em seus desejos, tudo isto que é imóvel e tudo isto que se move, e dizer que o ser e o todo são imóveis e móveis ao mesmo tempo" (Idem, p.249d).

Como se vê, estas páginas do Sofista, como aquelas do Pamênides, ainda que em sentidos diferentes, desvelam uma multiplicidade de contradições, aporias e mesmo teses opostas que os próprios Diálogos levantam contra uma suposta dogmática platônica das Idéias. Da mesma maneira, surgem também problemas nas tentativas de formulação da teoria das idéias que Sócrates realiza no Filebo. Aqui, Sócrates procura realizar, através da introdução de elementos quantitativos, a mediação entre o sensível e o inteligível. Propõe que se divida a totalidade dos seres em dois e, logo depois, como que hesitante, se corrige: "ou melhor, se queres, em três". (Platão, Filebo, p.23c). Em seguida, passa a nomear essas três "divisões" ou "gêneros": o primeiro seria o infinito (tó ápeiron), que corresponderia à unidade sensível; o segundo seria o finito (tó péras), que corresponderia à unidade inteligivel; "e como terceiro - diz ele - um outro que faz a sua mistura" (Platão, p.23c-d). Como se vê,

14 Cabe observar que realmente Sócrates está presente no diálogo, mas, como que intimidado por aquele que enfrentará o "pai Parmênides" - o Estrangeiro parricida - e já pesando sobre seus ombros a acusação da cidade (o Sofista é a continuação dramática do Teeteto, que termina com Sócrates se retirando para ir ao Pórtico do Rei para saber de que crimes é acusado), Sócrates melancolicamente permanecerá ouvindo em silêncio o desmoronamento da teoria dos "amigos das idéias" e a instauração do devir e da contradição no interior do próprio Ser absoluto. 
preocupa-se exatamente em estabelecer os elementos numéricos que participariam da mediação entre os domínios da realidade. No entanto, como já ocorrera, no Parmênides e no Sofista, aqui também dificuldades erguer-se-ão contra a dogmática das Idéias. Após nomear o primeiro elemento, nomeia o segundo, depois o terceiro e, como na idéia pensada como unidade sintética e como paradigma ${ }_{1}^{15}$ começa a emergir a série interminável, o argumento do $3^{\circ}$ Homem, o velho paradoxo da "má" infinitude. Assim é que, logo em seguida, é obrigado a nomear o quarto elemento, o que não faz sem antes se desculpar: "sou, parece, bem ridículo (geloiós), levando adiante divisões conforme espécies e enumerações" (Idem, p.23d). Protarco, o interlocutor, sem conhecer talvez 0 antigo paradoxo que sempre ressurge e atormenta a Sócrates desde a sua juventude, não compreende imediatamente onde está o "ridículo" e pergunta: "Que queres dizer, meu caro?" E Sócrates lhe explica: "É que tenho, parece, ainda necessidade de um quarto gênero" (Idem, ibid.). Este quarto será "a causa da mistura". Como afirma literalmente Sócrates: "Considera a causa da mistura destes, um em relação ao outro; coloco este como quarto em relação àqueles três" (Idem, ibid.). Evidentemente, estamos diante de uma série interminável: se depois dos dois primeiros foi necessário o terceiro e após este o quarto, não seria necessário depois o quinto gênero como "causa da separação" e assim sucessivamente a eclosão infinita de novos gêneros? Eis o que parece e é "ridículo"! E o jovem Protarco, mesmo sem conhecer o antigo paradoxo, mesmo sem reconhecer a antiga comicidade da nova solução socrática, ainda assim perguntará: "Não será necessário um quinto que tenha o papel de os separar?" (Idem ibid.). Sócrates, vacilante, como tantas e tantas vezes em momentos decisivos de outros diálogos, diante da pergunta a respeito do "quinto", responde evasivamente: "Talvez. Mas, eu penso, não agora. Entretanto, se ele for necessário, tu me perdoarás, eu imagino, se partir à procura de um quinto" (Idem, p.23e). Protarco, assim como não percebera a comicidade do paradoxo que se aproximava, não percebe também que com essa sua inocente indagação reconduzia Sócrates e a teoria das idéias ao insuperado labirinto parmenidiano. Só assim, graças à inexperiência juvenil de Protarco, pôde Sócrates continuar a sua exposição no diálogo Filebo. Mais uma vez, parece como se Platão estivesse destruindo a sua própria teoria nuclear. Assim, para defender a leitura dogmática da tradição, intérpretes do século XIX foram obrigados a considerar, como apócrifo, também o diálogo Filebo. ${ }^{16}$

Mas, depois desta passagem do Filebo, assim como daquelas do Parmênides e do Sofista, em que ainda poderíamos reencontrar dogmaticamente a doutrina central dos Diálogos, a Teoria das Idéias, aquela que, segundo a tradição, centraliza toda a série dos dogmas de Platão?

15 Platão - Parmênides: como unidade sintética, p.132a-b; como paradigma, p.132c-133a.

16 Por exemplo, Carl Schaarschmidt (1866), em seu livro Die Sammlung der platonischen Schriften, zur Scheidung der echten von den unechten untersucht, para defender a dogmática aristotélica, coerentemente, foi obrigado a considerar apócrifos os seguintes diálogos: Filebo, Parmênides, Sofista e Político. 
Talvez, nem mesmo, naquelas páginas do livro VI da República, aquelas páginas tão veneradas pela longa tradição ocidental. Um leitor atento, atento sobretudo à dramaticidade dialógica e assim à própria literalidade do texto, já pode perceber, mesmo ali, que a riqueza ontológica suprema da idéia de Bem é, na verdade, pobreza absoluta e cômica. A idéia de Bem epekeina tês ousias (509b) imediatamente após ser anunciada por Sócrates é ridicularizada por Glauco, o irmão de Platão. Como se lê literalmente no texto: "Então Glauco exclama de maneira muito engraçada (mála geloiôs): 'Por Apolo, diz ele, que divina transcendência!'”. Sócrates, se defendendo da ironia, replica: "Você também é culpado [do ridículo], pois me obrigou a dizer as opiniões que tenho sobre este assunto [o Bem]" (Platão, República, p.509c). Realmente, o próprio Sócrates, páginas atrás, quando pressionado a que falasse do Bem, advertira: "temo que isto ultrapasse minhas forças e que a minha forma inconveniente provoque risos (gélôta)" (Idem, p.506d). Como se vê, a célebre passagem da República - 509b-c - em que a tradição ocidental encontra o fundamento último do Bem transcendente do platonismo e a citação mais convincente da configuração de um "sistema" metafísico-dogmático em Platão provoca risos entre os interlocutores do próprio diálogo e, longe de ser a instituição solene de um dogma teológico-metafísico, se aproxima, ao menos um pouco, das cômicas Nuvens de Aristófanes. Se hoje a maioria dos comentadores não observa a problemática comicidade dessa cena, no entanto, ela está lá inscrita claramente na literalidade dramático-dialógica e abala, com o seu riso, todas as leituras dogmáticas que sonham, a partir daquela passagem, com uma possível demonstração do transcender teológico-metafísico de Platão. ${ }^{17}$

Na verdade, mesmo no interior desse livro VI da República, a pretensa dogmática platônica se dilui em risos. O Bem, Idéia das idéias, permanece indeterminado e é a sua indeterminação que provoca a comicidade. Sócrates é capaz somente de falar do filho do Bem, o Sol; ou seja, Sócrates é capaz de falar da região mais pura das idéias apenas por imagens sensíveis, imagens sensíveis estas que atestam 0 fracasso dialético de Sócrates. Ao falar da Idéia das idéias apenas por imagens, Sócrates demonstra a sua incapacidade de ascender além do domínio da dianóia. Ao contrário, o domínio puro da noésis, a região além de qualquer hipótese sensível, o momento propriamente dialético, permanece inatingido e inatingível, e este fracasso socrático reaparece em todas as outras tentativas: já na juventude fracassara diante de

17 Tanto esta problemática comicidade está inscrita inquestionavelmente na bruta literalidade dramático-dialógica que o velho Proclus, apesar de sonhar também (e talvez antes de todos) com o Bem transcendente de Platão, ao comentar esta passagem da República, foi obrigado a observá-la e a tentar contorná-la. Segundo Proclus, Glauco faz aquela exclamação "de maneira extremamente ridícula", pois ele não estaria ainda preparado para esses ensinamentos e "foi incapaz de fixar seu olhar sobre isto que é acima da Essência"(Proclus, v.II, p.72, X⿳⺈ Dissertação, 265, 15-30). A "culpa" da comicidade seria assim somente do inapto Glauco. Ora, no próprio texto, se realmente Sócrates também acusa o seu interlocutor, como vimos, é apenas para compartilhar a sua própria "culpa". Glauco seria culpado também, mas, apenas e tão somente, por ter obrigado Sócrates a discorrer sobre um assunto que o próprio Sócrates não conhecia suficientemente. Assim, segundo o texto, é Sócrates o inapto e não exclusivamente Glauco, como tortuosamente procura nos convencer Proclus. 
Parmênides que lhe demonstrara o caráter incognoscível de uma suposta região separada das idéias (diálogo Parmênides); o fracasso se repetirá no Filebo, no qual a argumentação permanecerá no domínio quantitativo das matemáticas, região ainda dianoética e, por isso mesmo, mais uma vez, se atingirá apenas "as portas do Bem", mas não o próprio Bem; ${ }^{18}$ e, finalmente, no diálogo Sofista, a intervenção de um novo personagem, o Estrangeiro de Eléia, refutará de maneira decisiva "os amigos das idéias" (e entre eles, Sócrates), demonstrando a noção de negatividade interna, o não-ser que é, e assim inaugurando uma outra dialética, uma dialética não-socrática e, principalmente, não-parmenideana. Mas, em tudo isso, onde está Platão? Onde está a palavra do soberano Mesmo, autós-Autor dos Diálogos?

Se o Bem socrático permaneceu indeterminado e, ao menos em parte, "aristofânico", se assim toda a teoria das idéias é enredada em uma multiplicidade de paradoxos tão claramente apontados no Parmênides, no Sofista e no Filebo, se as fissuras de um pretenso "sistema" de Platão são tão evidentes em tantos outros âmbitos, por exemplo, que resta da "teoria"do rei-filósofo após o diálogo Político? Que resta dos projetos políticos da República depois da teorização, desenvolvida nas Leis, dos conselhos eleitos diretamente pelos cidadãos? Se no Sofista se demonstra o ser do Não-Ser e, como o notou Deleuze, o próprio Sócrates (pretenso portador supremo dos dogmas de Platão) é cercado e cassado como sofista pelo Estrangeiro de Eléia, não seria hoje já chegado o momento de recomeçar novamente a perguntar, como se perguntou um dia na Antigüidade: onde estão os dogmas de Platão? Existem realmente os dogmas de Platão? A filosofia platônica não estaria contra e além de toda dogmática? ${ }^{19}$

\section{A Antigüidade e os dogmas de Platão}

“...nihil esse certi quo aut sensibus aut animo percipi possit..." (Arcesilau, segundo Cícero)

Realmente, a Antigüidade não teve tanta certeza a respeito da existência de uma dogmática de Platão. Como nos relata Sextus Empiricus (1976, livro I, 221, p.134-5): "Platão foi descrito por alguns como dogmático (dogmatikón), por outros

18 No Filebo, (Platão, 1956, p.65a), aproximando-se do final da sua demonstração, diz Sócrates: "dizemos que estamos agora nas portas de entrada do Bem" (tois tou agathou prothyrois, p.64c). E, logo adiante, se percebe que permanecerá realmente só e apenas "nas portas de entrada", assim é que se reconhece a impotência para apreender a idéia de Bem como um Um, por isso ela será tomada somente na multiplicidade, como a mistura de três elementos.

19 Deleuze (1969, p.295) tem o mérito de ter observado que, na última definição do sofista no diálogo Sofista, Sócrates aparece, paradoxalmente, como coincidindo com aquele. Sem tirar grandes conseqüências teóricas, ainda assim pergunta se o próprio Platão não estaria ali indicando, e pela primeira vez, o caminho do "renversement du platonisme". 
como aporético (aporetikón), e por outros como parcialmente aporético e parcialmente dogmático". Diógenes Laércio (1964, livro III, 51, p.142) também nos recorda que muita discussão (stásis) existia a respeito da interpretação dos Diálogos: alguns diziam que Platão exercia o "dogmatizar" (dogmatízein), outros diziam que não. Em outra passagem, Laércio (livro IX, 70, p.474) conta-nos que Teodósio colocava Platão entre os precursores de Pirron - o fundador do ceticismo. No interior da Média e da Nova Academia - desde Arcesilau, que assumiu a direção da escola em 270 a.C. -, sabe-se que a orientação fundamental era justamente combater os dogmatikoi - ou seja, os aristotélicos, epicuristas e estóicos. Assim escreveu Cícero no De Oratore (1930, livro III, p.67): "Arcesilau ... tira dos diversos escritos de Platão ... a conclusão que nada de certo pode ser apreendido, seja pelos sentidos, seja pelo espírito (nihil esse certi quo aut sensibus aut animo percipi possit...)"; e acrescenta que Arcesilau utilizava como método aquele "de não revelar o que pensa, mas argumentar contra o que os outros dizem pensar". No mesmo sentido, em outra obra, relata Cícero (1928, livro II, p.2) que Arcesilau teria recuperado e retomado como fundamental a prática do diálogo, abandonada pelos sucessores diretos de Platão - Espeusipo e Xenócrates, os diádokoi da chamada "Antiga Academia". Na mesma passagem da obra De Finibus, Cícero nos conta que aqueles que quisessem escutar Arcesilau não deveriam fazer questões e esperar discursos monológicos como resposta, mas sim, deveriam eles próprios dizer o que pensavam sobre determinado assunto e, a partir daí, sofrer as refutações de Arcesilau (Idem, ibid.). Assim, para Arcesilau, o exercício e o próprio conteúdo da Filosofia platônica era a prática da negatividade antidogmática. Esta interpretação da Filosofia platônica foi continuada no interior da Academia por Carneades, Clitômaco, Filon de Larissa e Antiocos de Ascalon, que inclusive foi professor de Cícero. ${ }^{20}$ Os partidários da Nova Academia teriam inclusive ido mais longe que os próprios céticos na sua negatividade; conforme Sextus, estes discípulos de Platão afirmavam "que todas as coisas são não-captáveis, e diferem dos céticos... pois afirmam isso firmemente, enquanto o cético vê como provável que algumas coisas podem ser apreendidas". ${ }^{21}$

A força desta tradição, através de toda a Antigüidade, é atestada pelo manual anônimo PROLEGOMENA, manual do século VI d.C. Este anônimo recorda os ensinamentos de Arcesilau, Carneades e as interpretações, hoje esquecidas, de que Platão, tanto quanto os céticos, professaria o caráter akataléptico, isto é, o caráter "não-captável" das coisas (Anônimo, 1990, p.15, 10 (1-5)). Os Prolegomena relatam

20 Sobre a história da Academia, escreve Sextus Empiricus (1976, livro I, p.220-221): "Segundo a opinião da maioria existiram três Academias - a primeira e mais antiga, aquela em torno de Platão, a segunda ou média Academia, aquela de Arcesilau, o discipulo de Polemos, a terceira ou nova Academia, aquela em torno de Carneades e Clitômaco. Alguns ainda acrescentam como quarta aquela de Filon e Cármidas; e alguns ainda catalogam aquela em torno de Antiocos como quinta".

21 Sextus Empiricus, 1976, livro I, p.226. Discutindo as interpretações da Nova e Média Academia ver: Annas, (1990); Levy, (1990). 
inclusive de maneira detalhada cinco argumentos que eram desenvolvidos para aproximar "Platão dos Céticos e dos Acadêmicos, sustentando que ele professa também que tudo é não-captável" . 22 Um dos argumentos é que Platão, quando realiza as suas afirmações, utiliza sempre expressões dubitativas que marcam hesitação: "provavelmente", "talvez", "sou levado a pensar". Ora, essas expressões não caracterizariam um homem que acredita realmente saber algo, mas sim, muito mais, "aquele que não possui um conhecimento determinado" (Idem, p.15). Outro argumento levantado é justamente a observação de que, como acima descrevemos em relação à chamada "Teoria das Idéias", "Platão estabelece teses opostas a respeito dos mesmos assuntos, mostrando assim claramente que a realidade é não-captável" (Idem, p.15-6). Os exemplos aqui citados são as discussões do Lysis, do Cármides e do Eutifron, em que teses opostas são sustentadas a respeito da amizade, da sabedoria e da piedade (Idem, p.16). Relata-nos ainda este Anônimo que, segundo os defensores dessa interpretação, Platão teria declarado: "Nada sei nem ensino, mas somente atravesso problemas (diaporôo mónon)" ${ }^{23} \mathrm{E}$ comentando essa frase, acrescenta o autor Anônimo: "Eis portanto como confessa [Platão], com sua própria boca, nada saber de maneira certa" (Idem, p.17).

Como se vê, a estranha luz de um Platão negativo e antidogmático atravessa toda a Antigüidade, se os dogmas a ela foram sobrepostos pela dominante tradição neoplatônica e aristotélica, ainda no crepúsculo do mundo antigo, ainda no século VI d.C., frases, como aquela recordada pelos Prolegomena, ainda ressoavam sustentando que o suposto "Mestre dos mestres", o suposto "divino" Platão de Jâmblico e Proclus, o Autor-autós soberano nada soubera ou ensinara e, longe das revelações absolutas, apenas praticara o diaporein. Ainda que vencidos, mal compreendidos e, finalmente, enterrados juntamente com o paganismo, não seriam estes lógoi mais próximos e mais fiéis ao próprio texto contraditório dos Diálogos?

Observando, na sua simples e bruta literalidade-dramática, a totalidade desses documentos textuais chamados "Diálogos de Platão", parece que tiveram realmente razão os que, como Arcesilau e Carneades, contestaram as leituras dogmáticas elaboradoras do sistema de Platão ou pensamento de Platão. Tiveram razão ao menos ao começarem a colocar entre parênteses essa preposição "de", essa preposição designando posse. Mas, seria esta negatividade contraditória dos Diálogos, como pensaram os Academikói, apenas a afirmação do negativo absoluto e da inexistência absoluta da verdade? Nos limites deste artigo já não podemos responder ou mesmo tentar responder esta questão. Gostaríamos, no entanto, um pouco à maneira dos mitos que tantas vezes encerram os Diálogos, de dar asas à imaginação hipotética e levantar algumas questões para finalizar este artigo.

22 A exposição dos cinco argumentos se estende da página 15 até 17.

23 Anônimo, 1990, p.17: oudén oida oute didáskôo ti, allá diaporôo mónon. 


\section{A hipótese da Dialética como Koinologia}

“..légetai dé hoos óntoos estí koiná tá philoon..."

(Leis, 739c)

Posto um Platão além do dogmatismo, como propuseram os Academikói, não estaríamos diante de uma negação e de uma ausência mais profundas que, meramente, a negação e a ausência da verdade? O diaporein contraditório e avassaladoramente negativo dos Diálogos não seria o próprio caminhar em si e por si de um pensamento sem sujeito e sem autor, sem Mesmo soberano? Platão, o próprio Platão, não esqueçamos, jamais tomou a palavra em seus próprios Diálogos. Na Carta II, escreve coerentemente ele ou outro que ele: "Não há obra de Platão e não existirá". ${ }^{24} \mathrm{O}$ diaporein contraditório e radicalmente negativo não seria o próprio escavar de um pensamento que, à procura do Universal concreto da Filosofia, o verdadeiro katolou, exatamente se caracterizaria pela supressão das determinações individuais que rompem o todo comum? Assim as ausências de sujeito e de autor individuais, as dificuldades de encontrar a centralização de um Mesmo soberano, a permanente supressão dos diversos lógoi individuais talvez sejam solidárias e complementares das supressões que se projetam no nível da praxis, as supressões propostas no programa sociopolítico que expõe a dialética dos Diálogos: aquelas da família patriarcal, da apropriação privada das mulheres e das crianças e, em geral, da apropriação privada de todas as coisas que são.

Passagens radicalmente comunistas, como aquela das Leis (739a-d), ${ }^{25}$ em que se imagina a ausência extrema da apropriação privada no nível da cidade, não seriam correlatas das ausências de um Autor (soberano proprietário privado do sentido) e de um Lógos Absoluto (proprietário privado da univocidade não-contraditória), ausências tão visíveis na estrutura dialógica-dialética desta obra conhecida como "de" Platão? Não seriam estas homólogas ausências o escavar da vertiginosa Ausência, aquela desenvolvida no diálogo Sofista, aquela que abre o caminho para o logos do Outro,

24 Platão, 1956, p.314e; contesta-se a autenticidade desta carta, mas atribui-se a sua autoria a círculos platônicos (ver J. Souilhé, Notice das Lettres nas Oeuvres Complètes , p.LXXXI).

25 Aqui se lê: "Se portanto ocorre já em algum lugar, ou se isto ocorrer um dia, que as mulheres sejam comuns, as crianças comuns e todos os bens comuns, que se procure por todos os meios suprimir da nossa vida isto que se chama a propriedade individual, que se chegue a tornar comuns de alguma maneira e na medida do possivel mesmo as coisas que a natureza deu comopróprias a cada homem, como os olhos, os ouvidos e as mãos, e que todos os cidadãos imaginem que vêem, que escutam, que agem em comum, que eles sejam, tanto quanto é possivel, unânimes em louvar ou criticar as mesmas coisas, que se alegrem ou se aflijam pelos mesmos motivos, enfim, que as leis estabeleçam na cidade a mais perfeita unidade que se possa realizar, jamais se colocará forma mais justa e melhor que esta para atingir a mais alta virtude. Em tal cidade, seja ela habitada pelos deuses ou pelos filhos dos deuses, ainda que sejam muitos, passarão sua existência na alegria" (citei a tradução de Émile Chambry, Paris: Garnier, s.d.). 
para a ousia do Não-Ser, para a negatividade interna ao próprio Ser? Neste diaporein radicalmente negativo, que suprime o próprio Ser como o objeto absoluto do logos, talvez estivesse a aurora de uma nova presença no domínio da Filosofia, a presença de uma nova ciência que estaria além da unilateralidade do dogma e da aporia, além da fixidez dos pólos negativo e positivo, além do negativo como externo ao positivo, uma ciência que seria transpassamento, elaboração da koinonia, koino-logia e, neste preciso sentido - fundar a racionalidade do-que-é comum -, dialética.

No entanto, nem os brilhantes dogmáticos (por exemplo, Aristóteles ou Proclus), nem os perspicazes céticos, como Sextus Empiricus, nem os próprios acadêmicos da negatividade, como Arcesilau e Carneades parecem ter compreendido ou retomado plenamente esta ciência então nascente. As formas desta epistême - dialética "platônica" - como disse certa vez Hegel, "permaneceram baldias por dois mil anos" (Hegel, 1965, p.253). Somente no século XIX, com o próprio Hegel, voltou-se a pensar o sentido profundo desta esotérica ciência, a filosofia especulativa, a filosofia dialética, além não somente dos dogmatikói, mas também dos academikói e dos skeptikói; além da unilateralidade do meramente positivo, do exclusivamente negativo e também da permanente procura cética. Talvez melhor que toda Antigüidade, e certamente melhor que toda Modernidade, ao retomar a filosofia dialética (e por isso mesmo) começou a compreender Hegel o diaporein negativo dos Diálogos, o negativo que como negação da negação ultrapassa a permanente procura negativa do ceticismo e ultrapassa também tanto a negação absoluta dos acadêmicos como a afirmação absoluta dos dogmáticos, e reencontra assim o conteúdo afirmativo no interior da própria negação. ${ }^{26} \mathrm{~A}$ obra "sem Autor" - Diálogos -, como começou a compreender e indicar Hegel, certamente não era dogmática (afirmação absoluta), talvez não fôsse acadêmica (negação absoluta), nem tampouco cética (permanente procura negativa), enquanto além de todas estas posições, talvez ela constituísse exatamente o ultrapassar dialético delas, ultrapassar este que a tradição ocidental - sempre tão narcisicamente fiel à apropriação privada das obras, dos pensamentos e das próprias coisas -, não por acaso, jamais soube retomar ou mesmo compreender. Como afinal os narcísicos amantes da Identidade, do Mesmo, da NãoContradição e das Ontologias ousio-lógicas do individual poderiam compreender os esboços da arcaica sabedoria comum dos verdadeiramente phíloi?

Na abertura dos seus Esboços de Pirronismo, Sextus Empiricus (livro I, 1-4, p.2-3) sustenta que existiriam três principais praticantes de filosofia: aqueles que acreditam haver descoberto a verdade, os dogmáticos, e cita, como exemplo, Aristóteles, Epicuro e os estóicos; em segundo lugar, aqueles que acreditam que a verdade é não-captável, e cita Clitômaco, Carneades e os Academikói em geral; e em terceiro lugar, aqueles que continuam a procurar a verdade, estes seriam os Céticos. A respeito dessa classificação, como citamos em nossa epígrafe, observou de maneira precisa Hegel:

26 Sobre os "limites" da leitura hegeliana de Platão, ver artigo recente em que desenvolvo o problema (Benoit, 1994). 
"Sextus distingue três filosofias. De Platão ele não sabe o que fazer" (Hegel, 1965, p.581). Hoje, após Hegel, após o século XIX, após o novo soterramento dogmático, cético e "acadêmico" da Dialética e da Filosofia, estaríamos nós, em relação aos Diálogos, em melhor situação que o velho Sextus? Sabemos nós, hoje, o que fazer de Platão?

BENOIT, A. H. R. Plato beyond dogmatism. Trans/Form/Ação (São Paulo), v.18, p.79-93, 1995.

- ABSTRACT: The aim of this article is to indicate the difficulties in maintaining a dogmaticinterpretation of Plato, and to develop some reflections about the relationships between dogmatism, scepticism and dialectics.

- KEYWORDS: Platonism; dogmatism; scepticism; dialectics.

\section{Referências bibliográficas}

1 ANNAS, J. Platon le sceptique. Revue de Métaphysique et Morale, n.2, 1990.

2 ANÔNIMO. Prolégomènes à la philosophie de Platon. Trad. e edição do texto por Trouillard Westerink. Paris: Les Belles Lettres, 1990.

3 ARISTÓTELES. Aristotle's Metaphysics. ROSS, W. D. (Ed.) London: Oxford University, 1958.

4 BENOIT, A. H. R. A dialética hegeliana como superação da dialética platônica. IDÉIAS, IFCH-UNICAMP, n.1, jan./jun. 1994.

5 CÍCERO. De Oratore De L'Orateur, Libre Troisième. Paris: Les Belles Lettres, 1930.

6 De Finibus Des Termes Extrêmes des Biens et des Maux. Paris: Les Belles Lettres, 1928. tomo I, livros I e II.

7 DELEUZE, G. Logique du Sens. Paris: Minuit, 1969.

8 DIËS, A. Notice. In: Parménide, Platon, Oeuvres Complètes. Paris: Belles Lettres, 1965, tomo VIII-1a parte.

9 DIÓGENES LAÉRCIO. Vitae Philosophorvm. H. S. Long. London: Oxford University, 1964. 10 GOLDSCHMIDT, V. A religião de Platão. São Paulo: Difel, 1962.

11 Les Dialogues de Platon. 3.ed. Paris: PUF, 1971.

12 HEGEL. Vorlesungen über die Geschichte der Philosophie. Glockner, Stuttgart: S. Werke, 1965. v. XVIII.

13 LEVY, C. Platon, Arcésilas, Carneade. Réponse à J. Anna. Revue de Métaphysique et Morale, n.2, 1990.

14 PLATÃO. Oeuvres Complètes. Paris: Les Belles Lettres, 1956. (Collection des Université s de France).

15 PROCLUS. Commentaire sur la République. Trad. e Notas de Festugière. Paris: Vrin- CNRS, 1970.

16 SCHAARSCHMIDT, C. Die Sammlung der platonischen Schriften. Bonn: A. Marcus, 1866.

17 SEXTUS EMPIRICUS. Outlines of Pyrnhonism. London: The Loeb Classical Library, 1976.

18 UEBERWEG, F. Untersuchungen über die Echtheit und Zeitfolge. Wien: C. Gerold's Sohn, 1861.

19 WOODRUFF, P.The Skeptical Side of Plato's Method. Revue Internationale de Philosophie, n.156-7, 1986. 